\title{
PERUMUSAN STRATEGI PEMASARAN \\ UNTUK MENINGKATKAN KEUNGGULAN KOMPETITIF PADA KOPERASI KUTA MIMBA DI KUTA BADUNG
}

\author{
I Nyoman Widya Arta ${ }^{1}$ \\ Kastawan Mandala ${ }^{2}$ \\ Program Studi Manajemen, Fakultas Ekonomi dan Bisnis Universitas Udayana \\ email:widyaarta.wa@gmail.com
}

\begin{abstract}
ABSTRAK
Koperasi merupakan salah satu lembaga keuangan yang memberikan jasa layanan keuangan berupa simpan pinjam tidak akan bisa lepas untuk dihadapkan kepada persaingan dari koperasi lain dan lembaga keuangan lainnya. Untuk itu lembaga koperasi sangat penting melakukan identifikasi faktor-faktor internal yang menjadi kekuatan dan kelemahan dari koperasi tersebut dan juga dapat mengidentifikasi faktor eksternal untuk dapat melihat peluang dan ancaman bagi koperasi sehingga mampu merumuskan strategi pemasaran yang tepat untuk memiliki keunggulan kompetitif bagi koperasi. Penelitian ini dilakukan di Koperasi Kuta Mimba dengan menggunakan metode wawancara kepada pengurus dan manjemen Koperasi Kuta Mimba, kemudian dilakukan analisa SWOT dan analisis IFAS, EFAS selanjutnya memberikan output berupa hasil analisa yang dijadikan dasar didalam menentukan merumuskan strategi. Berdasarkan hasil penelitian tersebut Koperasi Kuta Mimba saat ini seharusnya menerapkan strategi agresif, maka perusahaan dapat memanfaatkan kekuatan internalnya untuk meraih kesempatan/peluang yang ada, mengatasi masalah intern, dan menghindari ancaman-ancaman yang ada. Berkenaan dengan strategi agresif ini maka implementasinya berkaitan dengan penerapan strategi di segala bidang pada Koperasi Kuta Mimba melalui strategi pertumbuhan intensif dari WheelenHunger yang meliputi : Strategi Penetrasi Pasar (market penetration strategy), Strategi Pengembangan Pasar (market development strategy), dan Strategi Pengembangan Produk (product development strategy).
\end{abstract}

Kata Kunci: keunggulan kompetitif, strategi pemasaran, SWOT, strategi pertumbuhan intensif

\section{ABSTRACT}

A cooperative is a financial institution that provides financial services in the form of savings and loans that cannot be separated from being faced with competition from other cooperatives and other financial institutions. For this reason, cooperative institutions are very important to identify internal factors that are the strengths and weaknesses of the cooperative and can also identify external factors to be able to see opportunities and threats for cooperatives so that they are able to formulate appropriate marketing strategies to have a competitive advantage for cooperatives. This research was conducted at the Kuta Mimba Cooperative using the interview method to the management and management of the Kuta Mimba Cooperative, then carried out a SWOT analysis and IFAS analysis, EFAS then provided an output in the form of analysis results which were used as the basis for determining strategy formulation. Based on the results of this research, the Kuta Mimba Cooperative is currently supposed to implement an aggressive strategy, so the company can take advantage of its internal strength to seize opportunities / opportunities, overcome internal problems, and avoid existing threats. With regard to this aggressive strategy, its implementation is related to the implementation of strategies in all areas of the Kuta Mimba Cooperative through an intensive growth strategy from Wheelen-Hunger which includes: Market penetration strategy, market development strategy, and development strategy. Product (product development strategy).

Keywords: competitive advantage, marketing strategy, SWOT, intensive growth strategy 


\section{PENDAHULUAN}

Perkembangan koperasi dari waktu ke waktu terus meningkat salah satunya adalah koperasi simpan pinjam. Menurut Undang Undang Nomor : 25 Tahun 1992 tentang Perkoperasian pada Pasal 43 Ayat 4 dinyatakan, bahwa Koperasi menjalankan kegiatan usaha dan berperan utama di segala bidang kehidupan ekonomi rakyat. Kesempatan yang seluas-luasnya diberikan kepada koperasi untuk melakukan kegiatan usaha bidang perekonomian. Koperasi bebas melakukan kegiatan di bidang ekonomi rakyat baik sektor riil maupun pada sektor keuangan.

Sektor keuangan yang dikelola oleh Koperasi berupa Usaha Simpan Pinjam diatur lebih spesifik melalui Peraturan Pemerintah Nomor : 9 Tahun 1995 tentang Pelaksanaan Kegiatan Usaha Simpan Pinjam oleh Koperasi. Usaha simpan pinjam koperasi merupakan wadah pelayanan kebutuhan modal bagi anggota koperasi yang memiliki ketahanan dalam menghadapi gejolak ekonomi maupun moneter. Selain itu, usaha simpan pinjam koperasi merupakan salah satu bentuk konkrit peran serta masyarakat dalam pembangunan lembaga keuangan.

Perkembangan koperasi di Bali sebagian besar bergerak dalam unit usaha simpan pinjam. Salah satunya adalah Koperasi Kuta Mimba dengan memiliki wilayah operasional nifo provinsi, berlokasi di Jl. Sri Wijaya No. 18 Legian Kecamatan Kuta Badung. Berdasarkan Anggaran Dasar tahun 2008, Koperasi Kuta Mimba menyelenggarakan unit usaha pokok yaitu simpan pinjam dan pelayanan jasa yang selanjutnya disebut biro jasa, serta usaha-usaha lainnya yang syah untuk kesejahteraan anggota. Fokus penelitian ini yaitu pada unit usaha pokok simpan pinjam, yang berusaha untuk mencegah para anggotanya terlibat dalam jeratan kaum lintah darat ketika memerlukan sejumlah uang, dengan jalan menggiatkan tabungan dan mengatur pemberian uang dengan bunga yang serendah-rendahnya.

Meningkatnya jumlah kunjungan wisatawan dengan adanya obyek wisata di wilayah Kuta, Legian, dan Seminyak, mempunyai pengaruh terhadap pendapatan per kapita masyarakat. Ketiga wilayah tersebut, merupakan wilayah pangsa pasar utama Koperasi Kuta Mimba dikarenakan ketiga wilayah tersebut merupakan salah satu pusat perkembangan pariwisata yang paling diminati oleh para wisatawan ketika berkunjung ke Bali. Memiliki dampak positif pada penerimaan sektor pariwasata di ketiga wilayah ini, sehingga memberikan tambahan pendapatan asli daerah Kabupaten Badung dari peningkatan pendapatan perkapita sebagian besar masyarakatnya. Meningkatnya pendapatan masyarakat mendorong masyarakat untuk memenuhi kebutuhan hidupnya seperti melaksanakan kegiatan keagamaan yang rutin dilakukan, meningkatkan pendidikan anggota keluarga mereka, investasi maupun pengembangan usaha, serta kebutuhan hidup lainnya. Kondisi ini menjadi hal penting sebagai dasar perencanaan strategi bagi Koperasi Kuta Mimba karena dapat memberikan banyak peluang bagi operasional koperasi sehingga mampu berperan dalam upaya mewujudkan kesejahteraan masyarakat.

Seiring dengan perkembangan kemampuan keuangan Koperasi Kuta Mimba yang semakin baik, diputuskan untuk dilakukan perubahan badan hukum Koperasi Kuta Mimba melalui Perubahan Anggaran Dasar tahun 2015 dari badan hukum kabupaten menjadi badan hukum provinsi, sehingga diijinkan untuk melakukan perluasan layanan di seluruh wilayah Provinsi Bali. Perluasan wilayah pasar layanan yang dilakukan hingga saat ini sudah membuka kantor cabang layanan di empat kabupaten/kota yaitu Kabupaten Badung, Gianyar, Tabanan dan Kota 
Denpasar.

Dukungan dan kepercayaan masyarakat dalam memanfatkan layanan Koperasi Kuta Mimba menyebabkan Koperasi Kuta Mimba tetap eksis sampai saat ini. Perkembangan Koperasi Kuta Mimba dapat dimonitor melalui idikator yang menjadi parameter pertumbuhan koperasi sehingga dapat dilakukan evaluasi untuk mengetahui sisi kuat dan lemah dari Koperasi Kuta Mimba. Indikator yang bisa dijadikan parameter adalah jumlah anggota, asset, modal sendiri dan SHU. Perkembangan yang ditunjukkan di Koperasi Kuta Mimba dari sisi pertumbuhan anggota, asset, modal sendiri dan SHU dapat dilihat pada Tabel 1. Pada table tersebut ditampilkan 5 tahun terakhir perkembangan masing-masing indikator dan prosentase pertumbuhan setiap tahun. Anggota mengalami pertumbuhan namun tidak stabil bahkan pertumbuhannya terus mengalami penurunan di tahun 2018 dan 2019. Asset mengalami pertumbuhan yang baik walaupun sempat menunjukkan prosentase pertumbuhan menuru di tahun 2018 namun tahun 2019 mengalami pertumbuhan yang sangat tinggi dari tahun sebelumnya. Perkembangan modal sendiri juga menunjukkan pertumbuhan yang tidak stabil namun menunjukkan pertumbuhan mengembirakan di tahun 2019. Kemampuan untuk menghasilkan keuntungan berupa SHU juga sangat tidak stabil karena sempat mengalami penurunan dari capaian tahun sebelumnya walau kembali menunjukkan peningkatan di akhir tahun 2019.

Tabel 1.

Perkembangan Jumlah Anggota, Asset, Modal Sendiri danm SHU Koperasi Kuta Mimba Tahun 2015 - 2019

\begin{tabular}{lllllllll}
\hline Tahun & $\begin{array}{l}\text { Jumla } \\
\text { h } \\
\text { Anggot }\end{array}$ & \% & Asset (Rp) & \% & $\begin{array}{l}\text { Modal } \\
\text { Sendiri (Rp) }\end{array}$ & \% & SHU (Rp) & \% \\
& $\begin{array}{l}\text { a } \\
\text { (orang) }\end{array}$ & & & & & & & \\
& & & & & & \\
\hline 2015 & 5.165 & 5,8 & 137.257 .662 .6 & 7,67 & 17.646 .655 .7 & 3,50 & 3.052 .050 .4 & - \\
& & 2 & 31 & 8 & 79 & 9 & 14 & 22,9 \\
& & & & & & & & 2 \\
\hline 2016 & 5.428 & 5,0 & 152.117 .549 .4 & 10,8 & 22.273 .974 .3 & 26,2 & 3.585 .652 .5 & 17,4 \\
& & 9 & 05 & 3 & 25 & 2 & 02 & 8 \\
\hline 2017 & 6.389 & 17, & 169.101 .387 .7 & 11,1 & 22.027 .484 .9 & 2,43 & 3.348 .407 .4 & - \\
& & 70 & 00 & 6 & 55 & & 24 & 6,62 \\
\hline 2018 & 6.997 & 9,5 & 180.735 .209 .3 & 6,88 & 25.027 .484 .9 & 9,69 & 3.235 .451 .5 & - \\
& & 2 & 71 & & 55 & & 51 & 3,37 \\
\hline 2019 & 7.280 & 4,0 & 212.844 .688 .0 & 17,7 & 32.109 .728 .7 & 28,3 & 3.660 .971 .9 & 13,1 \\
& & 4 & 71 & 7 & 00 & 0 & 28 & 5 \\
\hline
\end{tabular}

Sumber : Laporan Pertanggungjawaban Pengurus Koperasi Kuta Mimba Tahun 2019

Partisipasi anggota menjadi indikator yang menjadi parameter perkembangan koperasi. Indikator dari partisipasi yang dapat dimonitor dalam perkembangan koperasi simpan pinjam adalah jumlah anggota yang meminjam, partisipasi masyarakat menyimpan dana di koperasi, besarnya dana dipinjamkan kepada anggota dan sejumlah pendapatan yang diperoleh dari partisipasi pinjaman anggota. Partisipasi anggota Koperasi Kuta Mimba dapat dilihat pada Tabel 2. yang menunjukkan prosentase partisipasi jumlah anggota meminjam menurun sehingga tidak mampu menyerap dana masyarakat yang disimpan di Koperasi Kuta Mimba 
yang jumlahnya sangat besar, nominal pinjaman yang beredar sangat kurang dari target sehingga menyebabkan kelebihan dana (idle cash) yang tentu akan menimbulkan beban biaya dana yang besar mengurangi pendapatan koperasi. Dengan demikian, Koperasi Kuta Mimba sebagai lembaga yang menjalankan fungsi intermediasi, belum mampu menjalankan fungsinya dengan maksimal.

Tabel 2.

Perkembangan Unit Simpan Pinjam Koperasi Kuta Mimba Tahun 2015 -

\begin{tabular}{cllllllll}
\hline $\begin{array}{c}\text { Tahu } \\
\mathbf{n}\end{array}$ & $\begin{array}{c}\text { Peminja } \\
\mathbf{m}(\mathbf{O r g})\end{array}$ & $\mathbf{\%}$ & $\begin{array}{c}\text { Dana } \\
\text { Masyarakat } \\
\mathbf{( R p )}\end{array}$ & $\mathbf{\%}$ & $\begin{array}{c}\text { Pinjaman } \\
\text { Beredar } \\
\mathbf{R p})\end{array}$ & $\begin{array}{c}\text { \% } \\
\text { Pendapatan } \\
\text { Bunga } \\
\mathbf{( R p )}\end{array}$ & $\mathbf{\%}$ \\
\hline 2015 & 1.554 & 15,5 & 109.691 .464$. & 1,63 & 121.319 .245$. & 8,90 & 18.152 .580$. & 9,65 \\
& & 4 & 654 & & 120 & & 252 & \\
\hline 2016 & 2.249 & 44,7 & 120.761 .153$. & 10,0 & 124.486 .020$. & 2,61 & 10.276 .997$. & 11,7 \\
& & 2 & 561 & 9 & 652 & & 300 & 0 \\
\hline 2017 & 3.385 & 50,5 & 136.234 .247$. & 12,8 & 146.738 .966$. & 17,8 & 23.584 .767$. & 16,3 \\
& 1 & 717 & 1 & 192 & 8 & 470 & 1 \\
\hline 2018 & 3.527 & 4,19 & 146.056 .214$. & 7,21 & 136.245 .842$. & - & 24.375 .608$. & 3,35 \\
& & & 587 & & 498 & 7,15 & 667 & \\
\hline 2019 & 3.419 & - & 176.988 .387$. & 21,1 & 144.971 .468$. & 6,40 & 26.439 .706$. & 8,47 \\
& & 3,06 & 180 & 8 & 132 & & 342 & \\
\hline
\end{tabular}

Sumber : Laporan Pertanggungjawaban Pengurus Koperasi Kuta Mimba Tahun 2019

Hasil yang dicapai oleh Koperasi Kuta Mimba selama 5 tahun terakhir tidak terlepas dari kemampuan pengelolaan dan faktor persaingan yang ada dalam layanan industri jasa keuangan yang berada di wilayah pasar layanan Koperasi Kuta Mimba. Dilihat dari sisi persaingan salah satu lembaga yang menjadi pesaing sudah tentu adalah koperasi. Pada Tabel 3 menunjukkan jumlah koperasi yang ada di seluruh kabupaten/kota di Provinsi Bali. Begitu besarnya jumlah koperasi yang tumbuh dan berkembang di wilayah Provinsi Bali menjadi hal yang sangat penting diperhatikan oleh pengurus dan manajemen Koperasi Kuta Mimba dalam mengelola koperasinya.

Tabel 3.

Jumlah Koperasi Primer Yang Ada di Seluruh Kabupaten/Kota di Bali Berdasarkan Jenis Usahanya

\begin{tabular}{lllllll}
\hline Kabupaten/Kota & $\begin{array}{c}\text { Level } \\
\text { Koperasi }\end{array}$ & $\begin{array}{c}\text { Koperasi } \\
\text { Produksi }\end{array}$ & $\begin{array}{c}\text { Koperasi } \\
\text { Konsumsi }\end{array}$ & $\begin{array}{c}\text { Koperasi } \\
\text { Pemasaran }\end{array}$ & $\begin{array}{c}\text { Koperasi } \\
\text { Simpan } \\
\text { Pinjam }\end{array}$ & $\begin{array}{c}\text { Koperasi } \\
\text { Serba } \\
\text { Usaha }\end{array}$ \\
\hline Jembarana & Primer & 31 & 194 & 2 & 37 & 89 \\
Tabanan & Primer & 34 & 259 & 1 & 285 & 223 \\
Badung & Primer & 20 & 428 & 3 & 108 & 347 \\
Gianyar & Primer & 6 & 1.067 & 0 & 163 & 830 \\
Klungkung & Primer & 7 & 71 & 1 & 60 & 32 \\
Bangli & Primer & 7 & 16 & 16 & 49 & 87 \\
Karangasem & Primer & 95 & 93 & 4 & 127 & 47 \\
Buleleng & Primer & 44 & 210 & 6 & 91 & 139 \\
\hline
\end{tabular}

Bersambung...

Lanjutan Tabel 3. 


\begin{tabular}{lllllll}
\hline Kabupaten/Kota & $\begin{array}{c}\text { Level } \\
\text { Koperasi }\end{array}$ & $\begin{array}{c}\text { Koperasi } \\
\text { Produksi }\end{array}$ & $\begin{array}{c}\text { Koperasi } \\
\text { Konsumsi }\end{array}$ & $\begin{array}{c}\text { Koperasi } \\
\text { Pemasaran }\end{array}$ & $\begin{array}{c}\text { Koperasi } \\
\text { Simpan } \\
\text { Pinjam }\end{array}$ & $\begin{array}{c}\text { Koperasi } \\
\text { Serba } \\
\text { Usaha }\end{array}$ \\
\hline Denpasar & Primer & 17 & 761 & 7 & 277 & 384 \\
Nivo Provinsi & Primer & 7 & 61 & 4 & 102 & 44 \\
\hline Jumlah/Total : & & 271 & 3.160 & 44 & 1.299 & 2.222 \\
\hline
\end{tabular}

Sumber: Badan Pusat Statistik Provinsi Bali 2019

Selain koperasi lembaga bank dan non bank juga menjadi ancaman karena kedua lembaga terseabut juga memberikan layanan yang sama dengan Koperasi Kuta Mimba. Keberadaan lembaga bank dan non bank sangat besar jumlahnya dan memberikan pelayanan yang juga sangat dirasakan oleh masyarakat di Bali. Jumlah bank dan non bank yang beroperasi di Bali ditampilkan dalam Tabel 4. berikut ini.

Tabel 4.

\begin{tabular}{lllll}
$\begin{array}{l}\text { Jumlah Bank Umum Pemerintah, Bank Umum Swasta, Bank Perkreditan } \\
\text { Rakyat (BPR) dan Lembaga NonBank di Provinsi Bali }\end{array}$ \\
\hline Kabupaten/Kota & $\begin{array}{c}\text { Bank Umum } \\
\text { Pemerintah }\end{array}$ & $\begin{array}{c}\text { Bank Umum } \\
\text { Swasta }\end{array}$ & $\begin{array}{c}\text { Bank } \\
\text { Perkreditan } \\
\text { Rakyat (BPR) }\end{array}$ & Non Bank \\
& & & 34 & 11 \\
Jembarana & 18 & 5 & 128 & 4 \\
Tabanan & 20 & 7 & 61 & 1 \\
Badung & 28 & 16 & 70 & 0 \\
Gianyar & 26 & 12 & 46 & 10 \\
Klungkung & 15 & 3 & 70 & 2 \\
Bangli & 9 & 3 & 68 & 10 \\
Karangasem & 17 & 4 & 24 & 109 \\
Buleleng & 24 & 9 & 21 & 6 \\
Denpasar & 36 & 22 & 522 & 153 \\
Bali & 193 & 81 & & \\
\hline
\end{tabular}

Sumber: Badan Pusat Statistik Provinsi Bali 2018

Satu lagi lembaga keuangan yang menjadi pesaing terdekat bagi Koperasi Kuta Mimba adalah lembaga keuangan yang merupakan kearifan lokal di Bali yaitu Lembaga Perkreditan Desa (LPD). Diketahui dari 1.433 LPD yang berkembang di Bali 909 adalah LPD yang dikategorikan sehat yang tersebar di sembilan kabupaten/kota di Bali. Sementara wilayah pasar utama Koperasi Kuta Mimba yaitu Kuta, Legian dan Seminyak merupakan wilayah desa adat yang memiliki LPD yang bahkan merupakan LPD terbesar di Bali.

Menjadi perjuangan yang sangat berat bagi pengurus dan manajemen Koperasi Kuta Mimba untuk tetap eksis sebagai koperasi yang tetap mampu memberikan layanan jasa keuangan terutama jasa simpan pinjam di tengah persaingan yang sangat ketat. Kemampuan pengurus dan manajemen dituntut untuk mampu merumuskan strategi pemasaran yang tepat untuk bisa eksis dan tetap memberikan pertumbuhan dalam persaingan pasar yang ada saat ini. Dalam persaingan dunia bisnis yang semakin ketat serta perkembangan teknologi yang semakin canggih dan modern, membuat perusahaan berusaha mencari strategi yang cepat dan tepat dalam memasarkan produk untuk memenuhi kebutuhan industri 
(Arie Wicaksono, 2018).

Permasalahan tersebut memerlukan perhatian dari pihak pengurus dan manajemen Koperasi Kuta Mimba dalam menjalankan operasional koperasi agar tetap bertahan dan senantiasa menunjukkan perkembangan yang positif dengan cara menerapkan strategi manajemen yang tepat. Dengan semakin berkembangnya Koperasi Kuta Mimba maka dukungan dan peran teknologi sangat dibutuhkan untuk membantu didalam melakukan operasional. Teknologi informasi telah menjadi fasilitas utama bagi kegiatan berbagai sektor kehidupan yang berkontribusi besar dengan perubahan dalam manajemen struktur organisasi dan operasi. Teknologi informasi memainkan peran penting dalam pengembangan peluang pasar (Sri Utami, 2012). Hal ini akan dapat meningkatkan pelayanan dan memberikan informasi dengan cepat, tepat dan akurat kepada nasabah dan anggotanya.

Pemanfaatan teknologi mempengaruhi efektivitas dan efisiensi operasional perusahaan, seperti penghematan biaya operasional yang dapat dilakukan dan berdampak pada keberlanjutan dan daya jangkau (Waspada, 2012). Penerapan teknologi ini jika dapat dilaksanakan dengan baik, akan menjadi salah satu faktor yang akan dapat menumbuhkan kepercayaan anggota dan masyarakat karena dapat menikmati pelayanan yang lebih baik sebagai kebutuhan saat ini dengan semakin majunya teknologi informasi dan komunikasi di era revolusi industri 4.0 saat ini.

Koperasi Kuta Mimba memberikan perhatian khusus kepada anggota dan masyarakat untuk mengetahui apa yang menjadi kebutuhan dan keinginan mereka. Hal ini akan berdampak pada kepercayaan anggota dan masyaarakat terhadap Koperasi Kuta Mimba tetap terpelihara bahkan meningkat. Kepercayaan nasabah menjadi hal penting dalam meningkatkan pelayanan bertransaksi (Alamsyah \& Anugrah, 2015). Kualitas pelayanan berpengaruh positif terhadap kepercayaan nasabah (Pramana \& Rastini, 2016), adanya pengaruh mediasi kualitas pelayanan dalam hubungan kepuasan nasabah terhadap kepercayaan nasabah (Guspul \& Ahmad, 2014) serta kepercayaan konsumen dan aksesbilitas memiliki dampak terhadap minat menabung nasabah bank (Setyawan \& Japarianto, 2014).

Kepercayaan anggota dan masyarakat akan dapat meningkatkan keinginannya untuk memanfaatkan jasa pelayanan Koperasi Kuta Mimba yaitu menyimpan dananya atau meminjam dana di Koperasi Kuta Mimba. Kepercayaan anggota dan masyarakat untuk menyimpan dananya di Koperasi Kuta Mimba adalah faktor yang sangat penting untuk berjalannya usaha simpan pinjam koperasi, karena anggota dan masyarakat sebagai sumber dana dan pengguna dana dari produk yang di pasarkan. Jika anggota dan masyarakat tidak dapat dilayani dengan baik maka mereka akan beralih ke para pesaing yang dianggap lebih baik dalam memenuhi keinginan mereka.

Berdasarkan hasil temuan peneliti ketika berkunjung ke Koperasi Kuta Mimba, pengurus dan manajemen Koperasi Kuta Mimba berusaha mengetahui kekuatan dan kelemahan koperasi melalui analisis lingkungan internal perusahaan. Analisis lingkungan internal yang dilakukan akan memberikan kekuatan jika variabel yang dievaluasi mampu menjadikan koperasi memiliki keunggulan utama tertentu. Lingkungan internal perusahaan menyangkut pemasaran dan distribusi dengan cara menawarkan jasa simpan pinjam oleh koperasi selanjutnya diketahui dan dimanfaatkan oleh anggota maupun masyarakat. 
Sebaliknya dikatakan memiliki kelemahan jika koperasi tidak mampu mengerjakan sesuatu yang dapat dikerjakan lebih mudah oleh pesaingnya. Jasa simpan pinjam ketika dimanfaatkan oleh nasabah maupun anggotanya, pengurus dan manajemen melakukan evaluasi terhadap operasional koperasi dan melaksanakan riset untuk mengetahui kebutuhan nasabah, mengadakan pengembangan produk guna mampu memenuhi kebutuhan pasar serta menciptakan produk baru untuk melayani potensi pasar yang ada. Dukungan sumber daya manusia yang berkualitas akan dapat menjalankan operasional koperasi dengan baik, efektif dan efisien sehingga modal koperasi dan dana nasabah yang masuk ke koperasi dapat dikelola dengan baik, aman sekaligus memberikan keuntungan.

Untuk mengantisipasi tantangan dan ancaman serta dapat melihat peluang, dalam menjalankan bisnis koperasi, harus dapat merumuskan strategi pemasaran dengan melihat perubahan dan perkembangan lingkungan yang ada dalam perusahaan yaitu lingkungan eksternal dan internal yang sangat berpengaruh terhadap perkembangan perusahaan. Koperasi harus mampu mengidentifikasi faktor-faktor lingkungan yang ada baik lingkungan eksternal maupun internal sehingga mampu melihat peluang dan ancaman serta mengetahui kekuatan dan kelemahan yang dimiliki oleh koperasi.

Analisis SWOT adalah evaluasi terhadap keseluruhan kekuatan, kelemahan, peluang, dan ancaman bagi perusahaan (Armstrong et al., 2018; Kotler \& Keller, 2012). Analisis SWOT merupakan identifikasi berbagai faktor secara sistematis untuk merumuskan strategi pemasaran, analisis ini didasarkan pada logika yang dapat memaksimalkan kekuatan (strength) dan peluang (opportunity), namun secara bersamaan dapat meminimalkan kelemahan (weakness) dan ancaman (threats). Matrik SWOT adalah alat yang dipakai untuk menyusun faktor-faktor strategi perusahaan, matrik ini dapat menggambarkan secara jelas bagaimana peluang dan ancaman yang dihadapi perusahaan dapat disesuaikan dengan kekuatan dan kelemahan yang dimilikinya (Rangkuti, 2019).

Analisis SWOT merupakan cara sistematik untuk mengidentifikasi faktorfaktor kekuatan dan kelemahan internal perusahaan serta peluang dan ancaman yang dihadapi perusahaan dan strategi yang menggambarkan kecocokan paling baik diantara mereka. Analisis ini dapat diasumsi bahwa strategi yang efektif akan memaksimalkan kekuatan dan peluang serta meminimalkan kelemahan dan ancaman.

Ikhtisar faktor strategis eksternal atau yang dikenal dengan istilah EFAS dapat disusun sedemikian rupa sehingga pimpinan industri dapat mengidentifikasikan faktor lingkungan eksternal yang paling kritis dan secara intensif memusatkan perhatian pada kemungkinan dampaknya terhadap strategi bisnis secara menyeluruh. Pimpinan industri hendaknya memusatkan perhatian pada lingkungan eksternal yang dipandang lebih berkembang, mudah berubah dan lebih bermusuhan (atau menguntungkan) serta terdapat ketergantungan organisasi yang lebih besar.

Faktor strategis eksternal (EFAS) menghendaki agar para peneliti strategi melakukan pengumpulan data dan menganalisis hal-hal yang menyangkut persoalan ekonomi, teknologi, peraturan perundangan pemerintah, kerja sama internasional, dan berbagai informasi tentang persaingan pada pasar industri tempat organisasi berada.

Dalam menjalankan usaha, pimpinan organisasi tidak boleh memilih satu di 
antara sekian banyak peluang yang ada pada suatu ketika yang mungkin membuahkan sukses besar kepadanya, kecuali pimpinan organisasi itu menyadari sepenuhnya tentang keunggulan strategisnya. Mereka tak akan mampu menghadapi ancaman lingkungan dengan efektif, kecuali kalau mereka secara teratur menganalisis kelemahan mereka sendiri. Dalam hal ini pimpinan organisasi dapat menyusun suatu matriks faktor strategis internal atau yang dikenal dengan nama IFAS (Internal Factor Analysis Summary), dengan cara meringkas beberapa diagnosis dari seluruh faktor lingkungan internal.

Alat perumusan strategi ini menyimpulkan dan mengevaluasi kekuatan dan kelemahan yang besar dalam daerah-daerah fungsional organisasi. Di samping itu juga untuk memberikan suatu basis bagi pengidentifikasian dan pengevaluasian hubungan diantara daerah-daerah tersebut. Pada intinya, analisis lingkungan internal ini dimaksudkan untuk mengidentifikasi dengan jelas kekuatan dan kelemahan organisasi pada waktu sekarang dan yang paling mungkin terjadi pada masa mendatang (Umar, 1998).

\section{METODE PENELITIAN}

Penelitian ini didesain dengan pendekatan kualitatif. Penelitian dilakukan dengan menggunakan wawancara kepada pengurus dan manajemen Koperasi Kuta Mimba dengan menggunakan indikator eksternal dan internal yang berkaitan dengan perumusan strategi pemasaran untuk meningkatkan keunggulan kompetitif sehingga diperoleh informasi tentang strategi, tantangan, peluang dan hambatan di dalam mengelola operasional Koperasi Kuta Mimba. Untuk kemudian dilakukan analisis IFAS, EFAS, dan dapat diketahui hasil analisa SWOT berdasarkan hasil wawancara yang dilakukan tersebut.

Penelitian ini dilakukan di Koperasi Kuta Mimba yang berlokasi di Jalan Sriwijaya No.18 Legian. Pemilihan lokasi penelitian ini karena Koperasi Kuta Mimba mampu meningkatkan jumlah anggota, asset, modal dan SHU selama lima tahun terakhir. Hal ini memiliki makna bahwa Koperasi Kuta Mimba merupakan koperasi yang tetap eksis dalam memberikan layanan kepada masyarakat dari tahun 1983 hingga saat ini namun belum mampu dimaksimalkan untuk mendapatkan manfaat berkoperasi dalam mewujudkan kesejahteraan anggotanya. Sedangkan objek dari penelitian ini adalah perumusan strategi pemasaran untuk meningkatkan keunggulan kompetitif pada Koperasi Kuta Mimba.

Variabel-variabel lingkungan eksternal dan internal yang diidentifikasi oleh manajemen Koperasi Kuta Mimba serta indikator yang berpengaruh terhadap kinerja Koperasi Kuta Mimba, dapat dilihat pada Tabel 5 dan Tabel 6.

Variabel yang termasuk kinerja eksternal yang digunakan terdiri dari lima (5) variabel. Variabel pertama, ekonomi terdiri dari dua indikator yaitu inflasi dan pendapatan per kapita. Variabel kedua, politik dan hukum terdiri dari dua indikator yaitu keadaan politik di Indonesia dan penegakan hukum. Variabel ketiga, sosial dan budaya terdiri dari tiga indikator yaitu gaya hidup masyarakat, tanggapan dan sikap masyarakat terhadap perkembangan dan budaya koperasi. Variabel keempat, persaingan usaha sejenis dengan koperasi dan variabel kelima, teknologi yang terdiri dari satu indikator yaitu kemajuan teknologi. 
Tabel 5.

Variabel dan Indikator Kinerja Eksternal Koperasi Kuta Mimba

\begin{tabular}{ll}
\hline \multicolumn{1}{c}{ Variabel } & Indikator \\
\hline Ekonomi & a) Inflasi \\
& b) Pendapatan Perkapita \\
Politik dan Hukum & a) Keadaan Politik di Indonesia \\
& b) Penegakan Hukum \\
Sosial dan Budaya & a) Gaya Hidup Masyarakat \\
& b) Tanggapan dan Sikap Masyarakat \\
& Terhadap Perkembangan \\
& c) Budaya Koperasi \\
Persaingan & Perkembangan Usaha Sejenis dengan \\
& Koperasi \\
Teknologi & Kemajuan Teknologi \\
\hline
\end{tabular}

Sumber : Koperasi Kuta Mimba, 2019

Variabel yang termasuk kinerja internal terdiri dari tiga (3) variabel. Variabel pertama, pemasaran yang terdiri dari empat (4) indikator : (1) pengembangan produk baru; (2) promosi; (3) tingkat suku bunga; dan (4) saluran distribusi. Variabel kedua, sumber daya manusia yang terdiri dari satu (1) indikator yaitu kualitas karyawan. Variabel ketiga, keuangan yang terdiri dari satu (1) indikator yaitu kemampuan keuangan dan variabel keempat, operasional perusahaan satu (1) indikator yaitu kegiatan operasional perusahaan.

Tabel 6.

Variabel dan Indikator Kinerja Internal Koperasi Kuta Mimba

\begin{tabular}{|c|c|c|c|}
\hline No & Variabel & \multicolumn{2}{|c|}{ Indikator } \\
\hline 1 & Pemasaran & $\begin{array}{l}\text { a) } \\
\text { b) } \\
\text { c) } \\
\text { d) }\end{array}$ & $\begin{array}{l}\text { Pengembangan Produk Baru } \\
\text { Promosi } \\
\text { Tingkat Suku Bunga } \\
\text { Saluran Distribusi }\end{array}$ \\
\hline 2 & Sumber Daya Manusia & \multicolumn{2}{|c|}{ Kualitas Karyawan } \\
\hline 3 & Keuangan & \multicolumn{2}{|c|}{$\begin{array}{l}\text { Kemampuan Keuangan (Total } \\
\text { Aset) }\end{array}$} \\
\hline 4 & Operasional Perusahaan & \multicolumn{2}{|c|}{ Kegiatan Operasional Perusahaan } \\
\hline
\end{tabular}

Sumber: Koperasi Kuta Mimba, 2019

Definisi operasional variabel adalah suatu definisi dari variabel dengan cara memberikan arti ataupun suatu operasional yang diperlukan agar dapat diukur. Definisi operasional masing-masing variabel yang digunakan pada Tabel 5. dan Tabel 6.

Jenis data menurut sifatnya yang dipergunakan dalam penelitian ini adalah. Data kuantitatif dan data kualitiatif. Data kuantitatif yang digunakan dalam penelitian ini adalah indikator internal dan eksternal sesuai pada Tabel 5 dan Tabel 6. Sedangkan data kualitatif yang digunakan dalam penelitian ini adalah struktur organisasi perusahaan, sejarah Koperasi Kuta Mimba, visi dan misi, strategi 
pemasaran perusahaan, serta keterangan mengenai perusahaan pesaing Koperasi Kuta Mimba yaitu LPD dan Bank-Bank yang ada di lingkungan wilayah operasional Koperasi Kuta Mimba.

Sumber data yang dipergunakan dalam penelitian ini menurut sumbernya yaitu Data primer dimana data primer yang digunakan meliputi variabelvariabel dari lingkungan internal dan eksternal yang mempengaruhi perusahaan, data mengenai pembobotan dan penilaian masing-masing indikatornya, serta hasil analisis kekuatan, kelemahan, peluang, dan ancaman (analisis SWOT) dari Koperasi Kuta Mimba. Selain itu data yang lainnya meliputi sejarah, visi dan misi, profil perusahaan, serta struktur organisasi perusahaan. Sedangkan Data sekunder yang dipergunakan meliputi data jumlah penduduk yang mempunyai penghasilan di 22 banjar dinas yang ada di Wilayah Kuta, Legian dan Seminyak serta cabang pengembangan pasar layanan yang merupakan wilayah kerja Koperasi Kuta Mimba, jumlah anggota dan nasabah Koperasi Kuta Mimba tahun 2019, laporan keuangan Koperasi Kuta Mimba tahun 2019, serta keterangan mengenai produk dan fasilitasnya.

Populasi dalam penelitian ini terdiri dari 5 orang pengurus dan 18 orang karyawan yang ada di level manajemen yaitu manajer sampai kasi yang dijadikan sebagai sampel. Sehingga metode penentuan sampel yang digunakan adalah metode teknik sampel jenuh, dikarenakan semua populasi digunakan sebagai sampel. Metode yang dipergunakan untuk pengumpulan data dalam penelitian ini adalah wawancara dan penyebaran kuesioner.

Teknik analisis data yang digunakan dalam penelitian ini adalah teknik analisis SWOT. Analisis SWOT, alat yang biasa digunakan untuk perencanaan strategis (Phadermrod et al., 2017) yang berguna untuk membuat keputusan semua jenis situasi di bisnis dan organisasi (Anggadwita et al., 2016; Bulis \& Skapars, 2012; Tahernejad et al., 2013). Analisis SWOT memahami bahwa peluang dan ancaman selalu potensial tergantung pada kemampuan strategis organisasi untuk melaksanakan kekuatan dan kelemahan komparatif(Vlados, 2019). Analisis SWOT menyoroti kekuatan, kelemahan, peluang dan ancaman dengan mengatasi faktor internal dan eksternal yang mempengaruhi perusahaan (Pai et al., 2013). Faktor dan tujuan strategis SWOT menunjukkan representasi sekmatis dari tiga tujuan strategis dan empat faktor SWOT dalam setiap kelompok SWOT dan tiga alternatif (Gro \& Stirn, 2015).

Pemberian bobot dan rating atas dasar hasil kuisioner. Bobot akan ditentukan dari masing-masing faktor strategis oleh para responden terpilih, dimana total keseluruhan harus sama dengan 1,00 atau 100 persen. Responden memberikan bobot tertinggi hingga terendah berdasarkan tingkat kepentingan faktor strategis tersebut terhadap kesuksesan perusahaan. Pembobotan dilakukan oleh responden dengan tujuan agar responden benar-benar mengetahui dampak variabel terhadap perusahaan. Skala nilai dari masing-masing responden akan dikumpulkan dan dicari rata-ratanya, nilai rata-rata itulah yang kemudian akan menjadi nilai bobot untuk masing-masing faktor.

Tabel 7.

Matrik Analisis SWOT

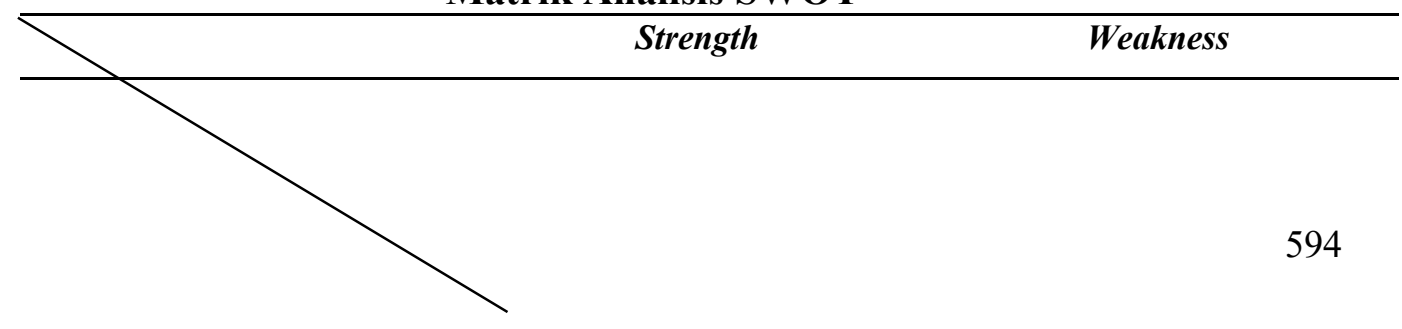




\begin{tabular}{|c|c|c|}
\hline $\begin{array}{l}\text { IFAS } \\
\text { EFAS }\end{array}$ & $\begin{array}{l}\text { Tentukan paling sedikit lima } \\
\text { item yang merupakan kekuatan } \\
\text { perusahaan }\end{array}$ & $\begin{array}{l}\text { Tentukan paling sedikit } \\
\text { lima item yang merupakan } \\
\text { kelemahan perusahaan }\end{array}$ \\
\hline \multicolumn{3}{|l|}{ Opportunities } \\
\hline \multirow[t]{2}{*}{$\begin{array}{l}\text { Tentukan paling sedikit lima } \\
\text { item yang merupakan peluang } \\
\text { bagi perusahaan }\end{array}$} & $\begin{array}{l}\text { 0-S Strategy Tentukan strategi } \\
\text { yang merupakan peluang bagi } \\
\text { perusahaan untuk } \\
\text { meningkatkan kekuatan }\end{array}$ & $\begin{array}{lr}\mathbf{0}-\mathbf{W} \text { Strategy } & \text { Tentukan } \\
\text { strategi yang } & \text { merupakan } \\
\text { peluang bagi } & \\
\text { perusahaan r untuk } & \\
\text { meminimalisasi kelemahan }\end{array}$ \\
\hline & & \\
\hline $\begin{array}{l}\text { Tentukan paling sedikit lima } \\
\text { item yang merupakan ancaman } \\
\text { bagi perusahaan }\end{array}$ & $\begin{array}{l}\text {-T-S Strategy Tentukan strategi } \\
\text { untuk mengantisipasi ancaman } \\
\text { dengan memanfaatkan } \\
\text { kekuatan perusahaan }\end{array}$ & $\begin{array}{l}\text { T-W Strategy } \\
\text { Tentukan strategi } \\
\text { mengantisipasi ancaman } \\
\text { untuk meminimalisasi } \\
\text { kelemahan perusahaan }\end{array}$ \\
\hline
\end{tabular}

Sumber : Rangkuti, 2019

\section{HASIL DAN PEMBAHASAN}

Berdasarkan hasil penelitian yang dilakukan di Koperasi Kuta Mimba dapat diketahui mengenai gambaran tentang karakteristik responden. Uraian tentang karakteristik responden akan dipaparkan secara rinci menurut jenis kelamin, lama bekerja, umur dan tingkat pendidikan.

Sifat dan sikap yang dimiliki oleh seorang laki-laki dan perempuan sangat menentukan dalam mengambil sebuah keputusan. Keterlibatan emosi, rasional, keberanian dan ketelitian adalah faktor yang sangat berbeda dimiliki oleh laki-laki dan perempuan. Pada penelitian ini menunjukkan jenis kelamin pada pengurus, dan level manajemen dari menejer, kepala bagian, kasi dan superviser yang menjadi responden hampir berimbang yaitu laki-laki 14 orang atau $45,16 \%$ dan perempuan sebanyak 17 orang atau 54,84\%

Analisis kekuatan, kelemahan, peluang, dan ancaman perusahaan merupakan suatu cara untuk mengetahui faktor-faktor strategis internal yang dimiliki perusahaan serta faktor-faktor strategis eksternal yang berpengaruh terhadap kinerja perusahaan. Berikut ini merupakan analisis kekuatan, kelemahan, peluang, dan ancaman dari Koperasi Kuta Mimba.

Tabel 8.

\section{Matrik Analisis SWOT}

\begin{tabular}{lcc}
\hline IFAS & Strength & Weakness \\
\cline { 2 - 3 } & 1) CustomerRelationship & 1) Konsep pemasaran, modern \\
\hline
\end{tabular}




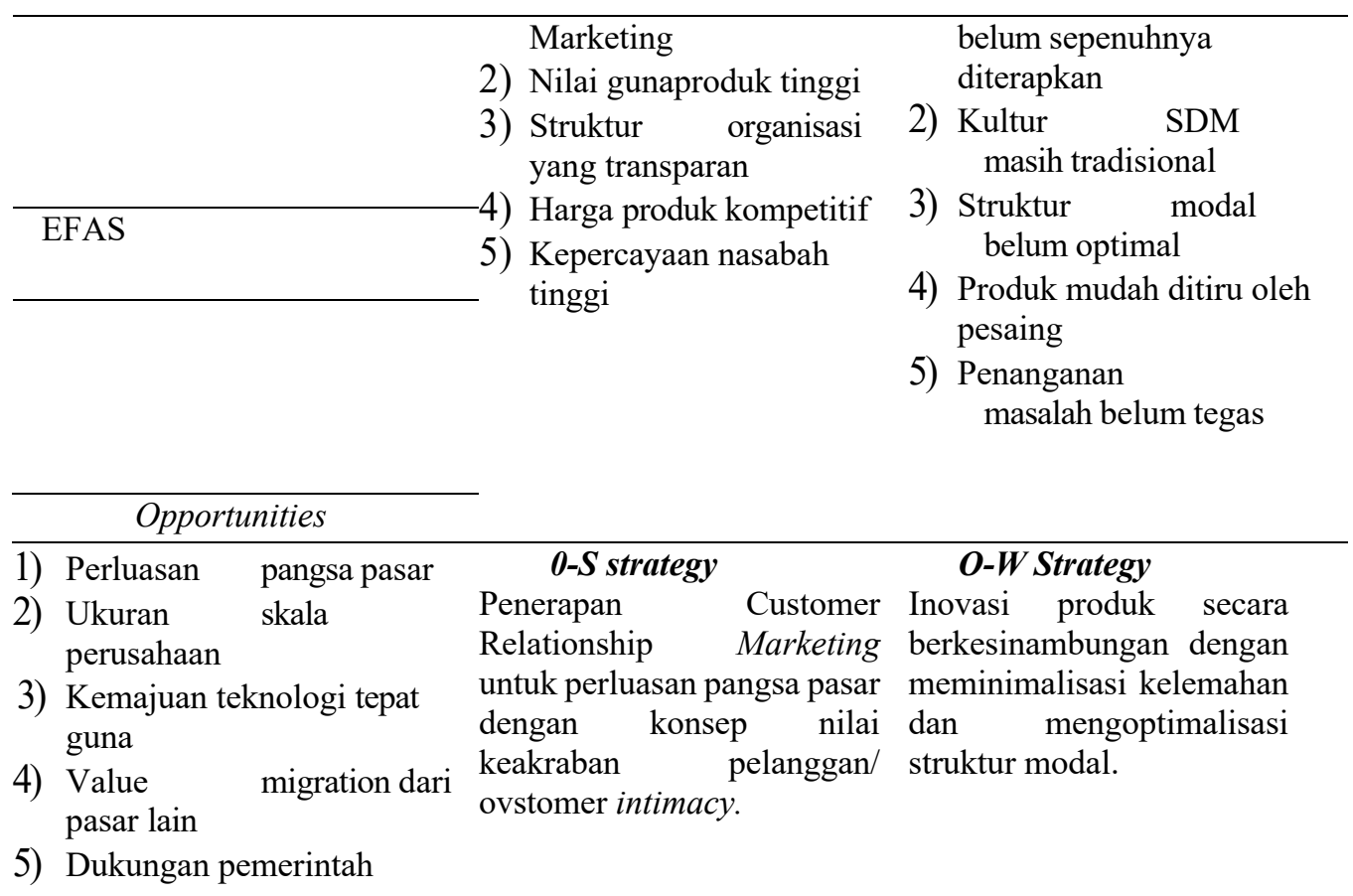

Threats

1) Globalisasi ekonomi

2) Kecemburuan sosial

3) Teknologi yangtertinggal dari negara maju

4) Stabilitas nasional

5) Persaingan dari pendatang baru

T-S Strategy
Perusahaan agar lebih
memfokuskan pada target
pasar yang lebih profitable
atau yang
menguntungkan.

T-W Strategy

Meningkatkan kapabilitas/ kemampuan setiap karyawan/ SDM untuk mengantisipasi berbagai ancaman globalisasi.

Sumber : data diolah, 2020

Pengurus Koperasi, Manajer dan karyawan dari Koperasi Kuta Mimba dipilih sebagai responden yang memberikan pendapat dan penilaiannya mengenai faktor strategis internal yang menjadi variabel dalam penelitian ini. Responden memberikan masukan mengenai kondisi internal Koperasi Kuta Mimba yang mempengaruhi, serta prediksi dari faktor internal tersebut. Kuisioner babak I meliputi pengidentifikasian variabel dan indikator variabel internal serta variabel dan indikator variabel eksternal. Kemudian kuisioner babak II meliputi pembobotan dan prediksi terhadap faktor strategis internal dan eksternal. Kuisioner babak III meliputi penilaian dari Pengurus Koperasi, Manager, masing- masing Kepala Bagian dan karyawan Koperasi Kuta Mimba terhadap faktor strategis internal dan eksternal.

Penelitian ini menunjukkan hasil pembobotan yang dilakukan oleh pengurus selaku manajemen puncak Koperasi Kuta Mimba beserta masing- masing manager dan karyawan terhadap faktor strategis internal. Pembobotan tersebut 
berdasarkan pada tingkat kepentingannya, sehingga dari masing-masing indikator yang dianggap paling penting diberikan bobot tertinggi kemudian menurun pada indikator yang dianggap kurang penting dan diberikan bobot yang rendah. Kekuatan pada Koperasi Kuta Mimba menurut responden variabel Struktur organisasi yang transparan dan Kepercayaan nasabah yang tinggi diberikan bobot 0,15 karena dianggap menjadi kekuatan utama dan kunci sukses terhadap perkembangan koperasi. Sedangkan variabel Customer Relationship Marketing, Nilai guna produk tinggi dan Harga produk kompetitif, semuanya diberikan bobot 0,10 karena dianggap oleh responden sama-sama memberikan kekuatan kepada Koperasi Kuta Mimba dalam hal menarik calon nasabah dan anggota serta memelihara kepercayaan anggota dan nasabahnya.

Tabel 9.

Perhitungan Internal Factor Analysis Summary (IFAS)

\begin{tabular}{|c|c|c|c|c|}
\hline \multirow[t]{2}{*}{$\begin{array}{l}\text { IFAS ( Internal Factors } \\
\text { Analysis Summary) }\end{array}$} & \multicolumn{3}{|c|}{$\begin{array}{l}\text { Perusahaan Koperasi Kuta } \\
\text { Mimba }\end{array}$} & \multirow[t]{2}{*}{ Catatan } \\
\hline & Bobot & Rating & $\begin{array}{l}\text { Bobot } x \\
\text { Rating }\end{array}$ & \\
\hline \multicolumn{5}{|l|}{ Strengths } \\
\hline 1. Nilai guna produk & 0,1 & 4 & 0,4 & Tingkatkan sektor ini \\
\hline 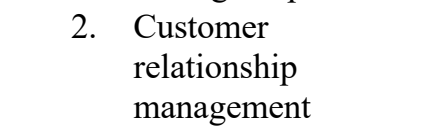 & 0,1 & 3 & 0,3 & Pertahankan kerjasama \\
\hline $\begin{array}{l}\text { 3. Struktur Organisasi } \\
\text { yang Transparan }\end{array}$ & 0,15 & 3 & 0,45 & Evaluasi kinerja \\
\hline $\begin{array}{l}\text { 4. Harga Produk } \\
\text { Kompetitif (suku } \\
\text { bunga simpanan dan } \\
\text { pinjaman }\end{array}$ & 0,1 & 3 & 0,3 & Pertahankan \\
\hline $\begin{array}{l}\text { 5. Kepercayaan } \\
\text { nasabah yang tinggi } \\
\text { Weakness }\end{array}$ & 0,15 & 4 & 0,6 & Pertahankan \\
\hline $\begin{array}{l}\text { 1. Aplikasi pemasaran } \\
\text { modern belum } \\
\text { sepenuhnya } \\
\text { diterapkan }\end{array}$ & 0,1 & 3 & 0,3 & $\begin{array}{l}\text { Kembangkan secara } \\
\text { berkesinambungan }\end{array}$ \\
\hline $\begin{array}{l}\text { 2. Kultur SDM masih } \\
\text { tradisional }\end{array}$ & 0,1 & 3 & 0,3 & Evaluasi kinerja \\
\hline $\begin{array}{l}\text { 3. Struktur modal } \\
\text { belum optimal }\end{array}$ & 0,1 & 2 & 0,2 & Kaji sturktur modal \\
\hline 4. Produk mudah ditiru & 0,05 & 2 & 0,1 & Tingkatkan inovasi \\
\hline
\end{tabular}
Bersambung...

Lanjutan Tabel 9.

\begin{tabular}{c|l|l|l|l}
\hline \multirow{2}{*}{$\begin{array}{l}\text { IFAS ( Internal Factors } \\
\text { Analysis Summary) }\end{array}$} & \multicolumn{3}{|l|}{$\begin{array}{l}\text { Perusahaan Koperasi Kuta } \\
\text { Mimba }\end{array}$} & Catatan \\
\cline { 2 - 4 } & Bobot & Rating & $\begin{array}{l}\text { Bobot x } \\
\text { Rating }\end{array}$ & \\
\hline $\begin{array}{l}\text { 5. Penanganan masalah } \\
\text { belum tegas terhadap }\end{array}$ & 0,05 & 4 & 0,2 & Evaluasi resiko \\
& & & &
\end{tabular}




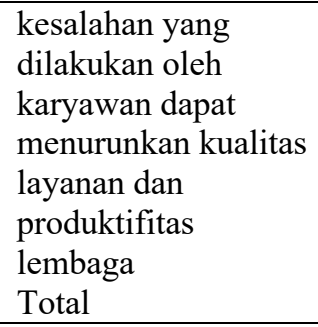

Dari segi kelemahan, indikator Aplikasi pemasaran modern belum sepenuhnya diterapkan, Kultur SDM masih tradisional, Struktur modal belum optimal, pelayanan kantor depan belum menjalankan tugas dan fungsinya dengan baik karena merupakan indikator yang berpengaruh terhadap kinerja perusahaan dan operasional perusahaan. Sedangkan indikator Produk mudah ditiru diberikan bobot sebesar 0,05 karena merupakan indikator yang berpengaruh tetapi karena produk perusahaan jasa simpan pinjam rata-rata sama di setiap perusahaan yang memberikan pelayanan ini maka responden menganggap variabel tersebut kecil pengaruhnya terhadap perkembangan perusahaan.

Setelah memberikan bobot untuk faktor strategis internal perusahaan, kemudian dilanjutkan dengan memberi rating atau penilaian untuk masing-masing faktor strategis internal. Skala nilai yang diberikan peneliti sesuai dengan pendapat dari responden maka skala nilai yang diberikan kepada responden digunakan untuk menentukan nilai masing-masing indikator tersebut.

Responden memberikan penilaian mengenai faktor strategis internal perusahaan untuk saat ini. Penilaian indikator untuk faktor strategis internal saat ini ditunjukkan pada Tabel 9 menunjukkan hasil penilaian dari responden terhadap faktor strategis internal perusahaan pada saat ini. Penilaian dari responden dapat dilihat pada indikator-indikator variabel internal antara lain Indikator Nilai Guna Produk, Harga Produk Kompetitif, Kepercayaan Nasabah Tinggi diberikan rating 4 (empat). Hal ini berarti indikator-indikator tersebut telah dilaksanakan dengan sangat baik oleh perusahaan. Sedangkan indikator Relationship Marketing, Struktur Organisasi Yang Transparan diberikan rating 3 (tiga) yang berarti indikator tersebut masih tetap dilaksanakan dengan baik oleh koperasi.

Sedangkan indikator-indikator Aplikasi Pemasaran Modern Belum Sepenuhnya Diterapkan dan Kultur SDM Masih Tradisional diberikan rating 3 (tiga) yang berarti bahwa kelemahan-kelemahan perusahaan tersebut dapat diminimalisasi dengan baik, kemudian indikator-indikator Struktur Modal Belum Optimal, Produk Mudah Ditiru, dan Kantor Dan Tempat Pelayanan Kurang Nyaman diberikan rating 2 (dua) yang berarti bahwa kelemahan tersebut baru dapat diminimalisasi sedikit atau beberapa.

Setelah memberikan bobot untuk faktor strategis internal perusahaan, kemudian Owner/General Manager beserta masing-masing Manager dan karyawan Koperasi Kuta Mimba memberikan bobot untuk faktor strategis eksternal perusahaan seperti yang ditunjukkan pada Tabel 10. Tabel 10. menunjukkan hasil pembobotan faktor strategis eksternal, proses pembebanan bobot sama dengan pembobotan pada faktor strategis internal perusahaan. Berikut ini merupakan penjelasan pembobotan dari masing-masing indikator. Peluang dari Koperasi Kuta 
Mimba meliputi indikator Perluasan Pangsa Pasar diberikan bobot tertinggi sebesar 0,15 karena dalam keadaan ekonomi serta masuknya era pasar bebas ke dalam negeri membuat sektor pariwisata semakin berkembang.

Koperasi Kuta Mimba yang berada pada daerah pariwisata perlu mengembangkan pangsa pasarnya guna dapat menjaga keseimbangan jumlah simpanan nasabah dengan kredit yang dilemparkan ke nasabah dan anggota. Indikator-indikator Ukuran Skala Perusahaan, Teknologi Tepat Guna, Value Migration Dari Pasar Lain dan Dukungan Pemerintah diberikan bobot sebesar 0,10 karena indikator-indikator ini merupakan peluang yang baik untuk meningkatkan kapasitas serta sumber daya yang dimiliki perusahaan. Sedangkan dari segi ancaman meliputi, indikator Ketertinggalan Teknologi Dari Negara Maju, Globalisasi ekonomi, Stabilitas Nasional, dan Persaingan Dari Pendatang Baru diberikan bobot sebesar 0,10 karena indikator-indikator tersebut dapat mempengaruhi perkembangan serta daya saing perusahaan. Sedangkan indikator Kecemburuan Sosial diberikan bobot sebesar 0,05 karena perkembangan koperasi akan mendapatkan respon atau tanggapan dari orang atau kelompok-kelompok orang yang ada di lingkungannya sehingga perlu tindakan antisipasi terhadap kemungkinan ancaman dari prilaku-prilaku orang-orang tersebut.

Tabel 10.

Perhitungan External Factor Analysis Summary (EFAS)

\begin{tabular}{|c|c|c|c|c|}
\hline \multirow[t]{2}{*}{$\begin{array}{l}\text { EFAS ( EksternalFactors } \\
\text { Analysis Summary) }\end{array}$} & \multicolumn{3}{|c|}{$\begin{array}{c}\text { Perusahaan Koperasi Kuta } \\
\text { Mimba }\end{array}$} & \multirow[t]{2}{*}{ Catatan } \\
\hline & Bobot & Rating & $\begin{array}{l}\text { Bobot } x \\
\text { Rating }\end{array}$ & \\
\hline \multicolumn{5}{|l|}{ Opportunities } \\
\hline $\begin{array}{l}\text { 1. Perluasan pangsa } \\
\text { pasar }\end{array}$ & 0,15 & 3 & 0,45 & Cari pasar baru \\
\hline $\begin{array}{l}\text { 2. Ukuran skala } \\
\text { perusahaan }\end{array}$ & 0,1 & 4 & 0,4 & kembangkan \\
\hline 3. Teknologi tepat guna & 0,1 & 3 & 0,3 & Pertahankan dan inovasi \\
\hline $\begin{array}{l}\text { 4. Value migration dari } \\
\text { pasar lain }\end{array}$ & 0,1 & 3 & 0,3 & Kaji konsumen baru \\
\hline $\begin{array}{l}\text { 5. Dukungan } \\
\text { pemerintah } \\
\text { Threats }\end{array}$ & 0,1 & 3 & 0,3 & Pertahankan dan inovasi \\
\hline 1. Globalisasi ekonomi & 0,1 & 2 & 0,2 & Evaluasi segmen pasar \\
\hline 2. Kecemburuan sosial & 0,05 & 3 & 0,1 & Perlu hati-hati \\
\hline $\begin{array}{l}\text { 3. Ketertinggalan } \\
\text { teknologi dari negara } \\
\text { maju }\end{array}$ & 0,1 & 2 & 0,2 & Kejar ketertinggalan \\
\hline 4. Stabilitas nasional & 0,1 & 2 & 0,2 & Regulasi pemerintah \\
\hline
\end{tabular}

Bersambung... 
Lanjutan Tabel 10.

\begin{tabular}{l|c|c|c|c}
\hline $\begin{array}{c}\text { EFAS ( EksternalFactors } \\
\text { Analysis Summary) }\end{array}$ & \multicolumn{3}{|c|}{ Perusahaan Koperasi Kuta } & \multirow{2}{*}{ Catatan } \\
\cline { 2 - 4 } & Bobot & Rating & $\begin{array}{c}\text { Bobot x } \\
\text { Rating }\end{array}$ & \\
\hline $\begin{array}{l}\text { 5. Persaingan dari } \\
\text { pendatang baru } \\
\text { Total }\end{array}$ & 0,1 & 2 & 0,2 & Evaluasi kinerja \\
\hline
\end{tabular}

Sumber : data diolah, 2020

Selanjutnya responden memberikan penilaian mengenai faktor strategis eksternal perusahaan yang dihadapi pada saat ini. Tabel 10. menunjukkan hasil penilaian dari responden terhadap faktor-faktor strategis eksternal perusahaan pada saat ini. Penilaian dari responden dihitung dan dapat dilihat pada penilaian skala masing-masing indikator. Indikator-indikator saat ini yang berada pada kisaran tersebut antara lain : indikator Ukuran Skala Perusahaan diberikan rating tertinggi yaitu 4 (empat) karena peluang ini sudah dapat dicapai dengan sangat baik. Indikator-indikator Perluasan Pangsa Pasar, Teknologi Tepat Guna, Value Migration Dari Pasar Lain dan Dukungan Pemerintah diberikan rating 3 (tiga) karena peluang ini juga telah dicapai oleh perusahaan dengan baik.

Indikator Globalisasi ekonomi, Kecemburuan Sosial, Ketertinggalan Teknologi Dari Negara Maju, Stabilitas Nasional dan Persaingan Dari Pendatang Baru diberikan rating 2 (dua) karena ancaman ini belum dapat diantisipasi secara optimal oleh perusahaan. Hasil akhir nilai tertimbang untuk Faktor Strategis Internal (IFAS) Koperasi Kuta Mimba saat ini adalah 3,15. Nilai 3,15 menunjukkan bahwa keadaan internal Koperasi Kuta Mimba pada saat ini cenderung kuat. Sedangkan hasil akhir nilai tertimbang Faktor Strategis Eksternal (EFAS) yang telah dilakukan mendapatkan hasil sebesar 2,65. Hasil tersebut menunjukkan bahwa keadaan eksternal Koperasi Kuta Mimba pada saat ini menunjukkan peluang bagi perusahaan.

Setelah merangkumkan hasil penilaian analisis data yang disaring pada proses analisis SWOT dan diukur secara kuantitatif pada tabel EFAS dan IFAS maka akan dapat dilihat pemilihan strategi yang tepat dengan menggunakan diagram analisis SWOT. Titik tengah diagram didapatkan dari rata-rata skala rating yaitu:

$$
\begin{array}{r}
\text { Titik tengah }(\text { nilai rata }- \text { rata })=\sum \frac{\text { skala penilaian }}{\text { banyaknya skala }} \ldots \ldots . \\
=\frac{4+3+2+1}{4} \\
=2,50
\end{array}
$$

Titik " 0 " adalah titik tengah diagram, yaitu nilai tengah 2,50. Nilai awal dari garis horizontal adalah di sebelah kiri dan nilai awal dari garis vertikal adalah dari sebelah bawah. Semakin ke kanan dan semakin ke atas, maka nilainya menjadi lebih besar. Batas nilainya di mulai dari 1 (satu) sampai 4 (empat) sesuai dengan skala penilaian. Hasil penilaian responden menunjukkan posisi Koperasi Kuta Mimba saat ini, yaitu posisi dengan faktor strategis internal 3,15 dan faktor strategis 
eksteraal 2,65. Setelah memasukkan nilai dari faktor strategis internal dan faktor strategis eksternal ke dalam diagram, maka didapatkan alternative strategi perusahaan dengan menggunakan diagram analisis SWOT yang ditunjukkan pada Gambar 1.

Berdasarkan diagram analisis SWOT pada Gambar 1, maka arah vektor pola penerapan strategi yang terpilih untuk Koperasi Kuta Mimba adalah strategi agresif karena mempunyai nilai faktor strategis eksternal (EFAS) yang bagus dan didukung oleh nilai faktor strategis internal (IFAS) yang baik. Berkenaan dengan strategi agresif ini maka implementasinya berkaitan dengan penerapan strategi di segala bidang pada Koperasi Kuta Mimba melalui strategi pertumbuhan intensif dari Wheelen- Hunger yang meliputi:

Strategi Penetrasi Pasar (market penetration strategy). Strategi ini berusaha untuk meningkatkan pangsa pasar suatu produk/jasa melalui usaha-usaha pemasaran yang lebih besar. Strategi ini dapat diimplementasikan oleh Koperasi Kuta Mimba melalui beberapa cara seperti menambah tenaga penjual dalam hal ini kolektor tabungan, menambah perlengkapan/sarana untuk promosi penjualan, atau dengan usaha promosi lainnya. Hal ini sesuai dengan temuan peneliti sebelumnya, penetrasi pasar mempengaruhi standar layanan pelanggan (Njogu \& Wanyoike, 2014), layanan yang ditawarkan (Njogu \& Wanyoike, 2014), strategi utama untuk bersaing meluncurkan produk inovatif yang digunakan sebagai strategi untuk meningkatkan penetrasi pasar (Rodrigues et al., 2012), penetrasi pasar dan strategi pengembangan pasar memiliki dampak signifikan terhadap biaya strategi kepemimpinan yang meningkatkan daya saing dan keunggulan kompetitif perusahaan (Alkasim et al., 2018).

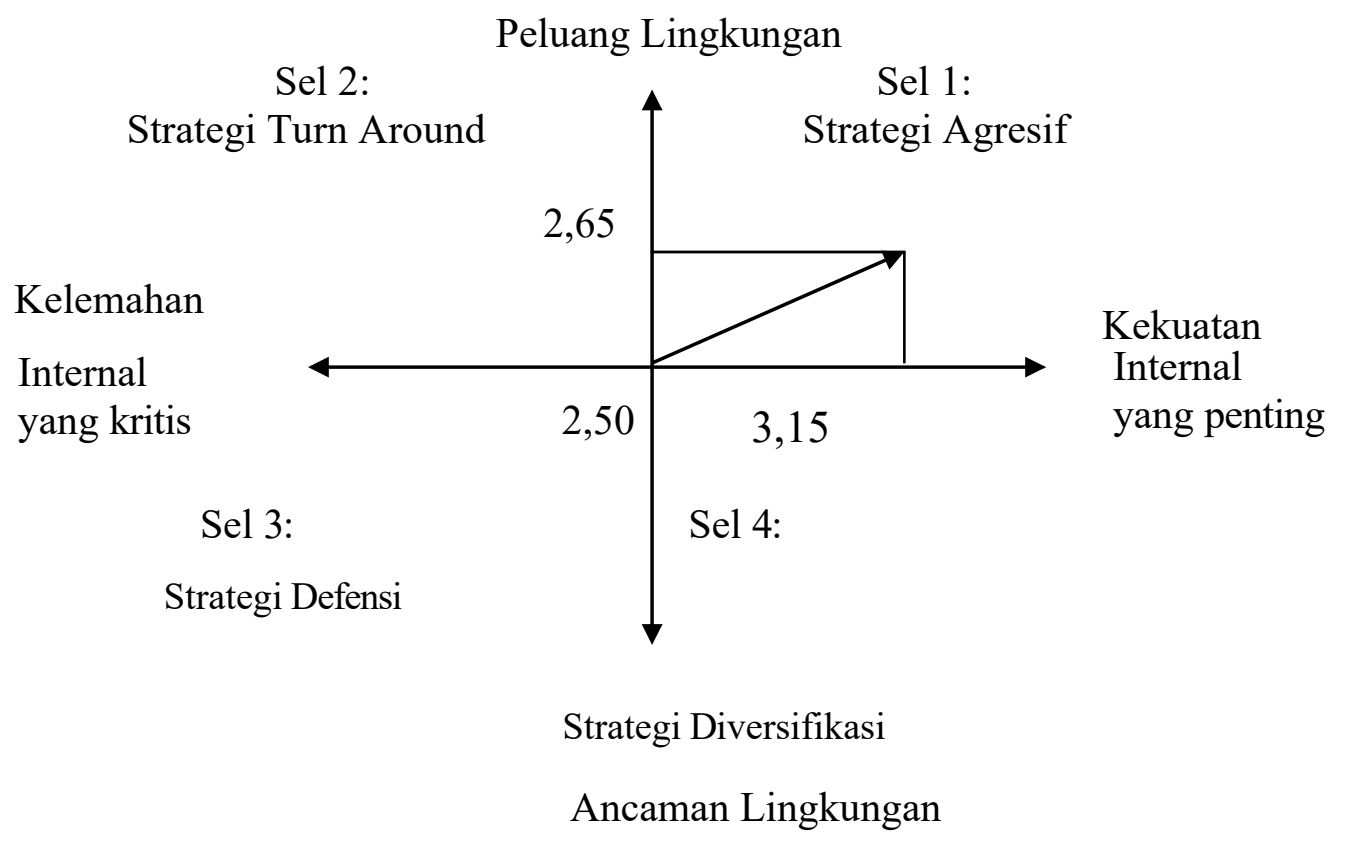

Gambar 1. Penentuan Strategi Analisis SWOT Peluang Lingkungan 
Strategi Pengembangan Produk (product development strategy). Strategi ini bertujuan agar perusahaan dapat meningkatkan penjualan dengan cara meningkatkan/memodifikasi produk/jasa yang ada sekarang. Koperasi Kuta Mimba dapat melakukan berbagai pengembangan produk dan jasa seperti, menambah jenis kredit yang bisa memberikan manfaat bagi nasabah dan anggota dengan memperhatikan situasi perekonomian saat ini, jenis dan bentuk tabungan, jenis pelayanan jasa yang dapat membantu dan memberikan manfaat lebih kepada nasabah, maupun menggunakan aplikasi layanan keuangan mobile. Sebuah studi empiris menjelaskan adanya korelasi antara pengetahuan metode manajemen dan strategi pengembangan produk baru (Liu et al., 2005). Dengan adanya terobosan produk baru untuk pasar dapat menghasilkan peluang yang terlewatkan (MacCormack et al., 2012). Pengembangan produk baru akan memberikan kesempatan untuk memasarkan hasil lokal dan menciptakan peluang kerja (Natsuda et al., 2012). Keterlibatan pelanggan dalam pengembangan produk merupakan salah satu strategi pemasaran, sehingga perusahaan dapat mengambil manfaat serta dapat meningkatkan strategi pemasaran dan membangun komitmen (Hollensen, 2015; Svendsen et al., 2011). Temuan lainnya, pengembangan produk baru menghasilkan hasil yang lebih baik (Yuen, 2014).

\section{SIMPULAN DAN SARAN}

Penelitian ini menyimpulkan bahwa variabel internal menunjukkan kekuatan perusahaan dengan nilai tertimbang variabel dari masing-masing indikator adalah sebesar 3,15. Indikator yang menjadi kekuatan bagi Koperasi Kuta Mimba untuk saat ini meliputi indikator Nilai guna produk, Harga produk kompetitif, Kepercayaan nasabah tinggi. Selain itu perusahaan juga mempunyai kelemahan pada indikator Aplikasi pemasaran modern belum sepenuhnya diterapkan, Kultur SDM masih tradisional, Struktur modal belum optimal, Produk mudah ditiru, Pelayanan kantor depan belum menjalankan tugas dan fungsinya dengan baik. Variabel eksternal untuk saat ini mempunyai nilai tertimbang sebesar 2,65 yang menunjukkan peluang bagi perusahaan. Indikator yang menjadi peluang bagi Koperasi Kuta Mimba untuk saat ini adalah Perluasan Pangsa Pasar, Ukuran Skala Perusahaan, Teknologi Tepat Guna, Value Migration Dari Pasar Lain, dan Dukungan Pemerintah. Sedangkan ancaman yang diantisipasi dan dihindari oleh perusahaan meliputi indikator Globalisasi Ekonomi, Kecemburuan Sosial, Ketertinggalan teknologi dari negara maju, stabilitas nasional, dan persaingan dari pendatang baru.

Strategi yang menjadi alternatif untuk Koperasi Kuta Mimba dalam meningkatkan keunggulan kompetitif pada masa sekarang adalah strategi yang memaksimalkan kekuatan yang dimiliki dengan memanfaatkan peluang-peluang yang ada. Pilihan alternatifhya yaitu strategi agresif, dimana implementasinya berkaitan dengan strategi pertumbuhan intensif dari Wheelen-Hunger yang meliputi strategi penetrasi pasar, strategi pengembangan pasar, dan strategi pengembangan produk. Adapun saran yang diberikan dalam penelitian ini yaitu Koperasi Kuta Mimba untuk saat ini berada pada Sel/kuadran 1 yaitu pada strategi Agresif. Dimana dalam strategi tersebut perusahaan bisa lebih meningkatkan pelayanan 
yang dimiliki dengan memanfaatkan kekuatan dan peluang yang ada, di samping mempelajari dan membenahi berbagai kelemahan dan ancaman yang ada agar dapat diubah menjadi kekuatan dan peluang bagi perusahaan, seperti menambah jenis produk/jasa tabungan dan kredit, mempermudah proses administrasi yang meliputi kemudahan dalam memperoleh kredit, meningkatkan mutu pelayanan dan kualitas produk yang dimiliki, meningkatkan penggunaan teknologi tepat guna, memberikan pelayanan terbaik untuk mencapai kepuasan dan loyalitas nasabah dan anggota. Menghadapi tingkat persaingan dan perubahan dalam kurun waktu lima tahun ke depan, sumber daya yang dimiliki perusahaan saat ini sudah menjadi sangat terbatas kapasitasnya dalam mendukung perusahaan untuk meraih tujuannya. Oleh sebab itu, dalam perusahaan harus terdapat keseimbangan antara alokasi sumber daya, perencanaan, penerapan dan pengendalian strategis perusahaan yang diselaraskan dengan tuntutan lingkungan industri dan sosial perusahaan. Perusahaan hendaknya memberikan berbagai bentuk pelatihan maupun pendidikan (diklat internal dan eksternal) bagi sumber daya manusia/karyawan dalam rangka meningkatkan kualitas dan kinerja karyawan, serta meningkatkan kemampuan bersaing tiap karyawan agar dapat mengantisipasi dan menghindari setiap ancaman yang datang pada era globalisasi.

\section{REFERENSI}

Alamsyah, D. P., \& Anugrah, R. (2015). Membangun Kepercayaan Nasabah Pada Internet Banking. Ecodemica, 3(2), 464-473.

http://ejournal.bsi.ac.id/ejurnal/index.php/ecodemica/article/view/33

Alkasim, S. B., Hilman, H., Bohari, A. M. Bin, Abdullah, S. S., \& Sallehddin, M. R. (2018). The mediating effect of cost leadership on the relationship between market penetration, market development, and firm performance. Journal of Business and Retail Management Research, 12(3), 190-200. https://doi.org/10.24052/jbrmr/v12is03/art-17

Anggadwita, G., Saragih, R., \& Alamanda, D. T. (2016). Competitive Strategy of Creative Application Content in the ASEAN Economic Community : Software Development using SWOT Analysis in Indonesia. International Journal of Economics and Management, 10, 95-107.

Arie Wicaksono. (2018). Strategi Pemasaran dengan menggunakan Analisis SWOT Tanpa Skala Industri Pada PT X Di Jakarta. Jurnal Manajemen Industri Dan Logistik, 1(2), 204. https://doi.org/10.30988/jmil.v1i2.54

Armstrong, G., Agnihotri, P., \& Kotler, P. T. (2018). Principle Of Marketing (17th Editi). Pearson. https://sites.google.com/site/lakkantalad/kar-wangphaen-kartlad

Badan Pusat Statistik Provinsi Bali 2019 
Bagautdinova, N., Gafurov, I., Kalenskaya, N., \& Novenkova, A. (2012). The regional development strategy based on territorial marketing (The Case of Russia). World Applied Sciences Journal, 18(SPL.ISSUE. 18), 179-184. https://doi.org/10.5829/idosi.wasj.2012.18.120030

Bulis, A., \& Skapars, R. (2012). Competitiveness of European Companies in China: A SWOT Analysis. International Journal of Economics and Finance Studies, $4(2), 1-10$.

Edvardsson, B., Meiren, T., Schäfer, A., \& Witell, L. (2013). Having a strategy for new service development - does it really matter? Journal of Service Management, 24(1), 25-44. https://doi.org/10.1108/09564231311304170

Gro, P., \& Stirn, L. Z. (2015). The environmental management problem of Pohorje , Slovenia: A new group approach within ANP e SWOT framework. Journal of Environmental Managemeng, 161, 106-112. https://doi.org/10.1016/j.jenvman.2015.06.038

Guspul, A., \& Ahmad, A. (2014). Kualitas Pelayanan, Kepuasan Dan Kepercayaan Nasabah Pada Koperasi Jasa Keuangan Syariah Di Wonosobo. Jurnal PPKM III, 156-170.

Hollensen, S. (2015). Marketing Management A Relationship Approach (3rd ed.). Pearson. http://library1.nida.ac.th/termpaper6/sd/2554/19755.pdf

Kotler, P., \& Keller, K. L. (2012). Marketing Management (14th Editi). Prentice Hall.

Laporan Pertanggungjawaban Pengurus Koperasi Kuta Mimba Tahun 2019

Liu, P. Lo, Chen, W. C., \& Tsai, C. H. (2005). An empirical study on the correlation between the knowledge management method and new product development strategy on product performance in Taiwan's industries. Technovation, 25(6), 637-644. https://doi.org/10.1016/j.technovation.2003.11.001

MacCormack, A., Crandall, W., Henderson, P., \& Toft, P. (2012). Do you need a new product-development strategy? Research Technology Management, 55(1), 34-43. https://doi.org/10.5437/08956308X5501014

Natsuda, K., Igusa, K., Wiboonpongse, A., \& Thoburn, J. (2012). One village one product - Rural development strategy in Asia: The case of OTOP in Thailand. Canadian Journal of Development Studies, 33(3), 369-385. https://doi.org/10.1080/02255189.2012.715082

Njogu, A. M., \& Wanyoike, D. M. (2014). Influence of Customer Satisfaction on Market Penetration Strategy of Agency Banking at Cooperative Bank of Kenya -Nakuru Town. International Journal of Arts and Commerce, 3(2). 
Pai, M., Chu, H., Wang, S., \& Chen, Y. (2013). Knowledge-Based Systems Ontology-based SWOT analysis method for electronic word-of-mouth. Knowledge-Based Systems, 50, 134-150. https://doi.org/10.1016/j.knosys.2013.06.009

Peraturan Pemerintah Nomor : 9 Tahun 1995

Phadermrod, B., Crowder, R. M., \& Wills, G. B. (2017). Importance-Performance Analysis based SWOT analysis. International Journal of Information Management, 1-10. https://doi.org/10.1016/j.ijinfomgt.2016.03.009

Pramana, I. G. Y., \& Rastini, N. M. (2016). Pengaruh Kualitas Pelayanan terhadap Kepercayaan Nasabah dan Loyalitas Nasabah Bank Mandiri Cabang Veteran Denpasar Bali. E-Jurnal Manajemen Unud, 5(1), 706-733. ojs.unud.ac.id

Rangkuti, F. (2019). Teknik Membedah Kasus Bisnis Analisis SWOT: Cara Perhitungan, Bobot, Rating dan OCAI. Gramedia Pustaka Utama.

Rodrigues, L. C., Maccari, E. A., \& Lenzi, F. C. (2012). Innovation Strategy for Business to Business Market Penetration. International Business Research, 5(2), 137-149. https://doi.org/10.5539/ibr.v5n2p137

Setyawan, Y. N., \& Japarianto, E. (2014). Analisa Pengaruh Kepercayaan, Jaminan Rasa Aman, dan Aksesbilitas terhadap Minat Menabung Nasabah Bank Danamon di Surabaya. Jurnal Manajemen Pemasaran Petra, 2(1), 1-8. https://media.neliti.com/media/publications/132217-ID-analisa-pengaruhkepercayaan-jaminan-ras.pdf

Sri Utami, S. (2012). Pengaruh Teknologi Informasi dalam Perkembangan Bisnis. Jurnal Akuntansi Dan Sistem Teknologi Informasi, 8, 61-67. ejurnal.unisri.ac.id

Svendsen, M. F., Haugland, S. A., Grønhaug, K., \& Hammervoll, T. (2011). Marketing strategy and customer involvement in product development. European Journal of Marketing, 45(4), 513-530. https://doi.org/10.1108/03090561111111316

Tahernejad, M. ., Ataei, M., \& Khalokakaei, R. (2013). A Strategic Analysis of Iran's Dimensional Stone Mines Using SWOT Method. Arab Jlournal for Science and Engineering, 38, 149-154. https://doi.org/10.1007/s13369-0120422-Z

Umar, H. (1998). Strategic Management in Action. PT. Gramedia Pustaka Utama.

Undang Undang Nomor : 25 Tahun 1992 tentang Perkoperasian 
I Nyoman Widya Arta, Perumusan Strategi Pemasaran...

Vlados, C. (2019). On a correlative and evolutionary SWOT analysis. Journal of Strategy and Management, 12(3), 347-363. https://doi.org/10.1108/JSMA02-2019-0026

Waspada, I. (2012). Percepatan Adopsi Sistem Transaksi Teknologi Informasi Untuk Meningkatkan Aksesibilitas Layanan Jasa Perbankan. Jurnal Keuangan Dan Perbankan, 16(1), 122-131. jurkubank.wordpress.com

Xia Chan. (2011). A SWOT study of the development strategy of Haier Group as one of the most successful Chinese enterprises. International Journal of Business and Social Science, 2(11), 147-153. www.ijbssnet.com

Yuen, K. K. F. (2014). Fuzzy cognitive network process: Comparisons with fuzzy analytic hierarchy process in new product development strategy. IEEE Transactions on Fuzzy Systems, 22(3), 597-610. https://doi.org/10.1109/TFUZZ.2013.2269150 